\title{
Methods for Integrating Transdisciplinary Teams in Support of Reciprocal Healing: A Case Study
}

Sara L. Warber, ${ }^{1,2}$ Katherine N. Irvine, Bridget F. Quinn, ${ }^{1,4}$ Amelia L. Hansen, ${ }^{5}$ Cinder Hypki, and Elaine Sims ${ }^{7}$

${ }^{1}$ Department of Family Medicine, The University of Michigan, Ann Arbor, Michigan, USA.

${ }^{2}$ European Centre for Environment and Human Health, University of Exeter Medical School, Knowledge Spa, Truro, United Kingdom.

${ }^{3}$ Social, Economic and Geographical Sciences Department, James Hutton Institute, Aberdeen, United Kingdom.

${ }^{4}$ The A.W.E. Society, Warren, Michigan, USA.

${ }^{5}$ Southwest Michigan Land Conservancy, Galesburg, Michigan, USA.

${ }^{6}$ Hypki Consulting, Baltimore, Maryland, USA.

${ }^{7}$ Gifts of Art Program, Michigan Medicine, The University of Michigan, Ann Arbor, Michigan, USA.

\section{Abstract}

We live in a time of accelerated environmental change. Links between ecosystem health and human health and well-being are increasingly recognized with ever more awareness of impending environmental catastrophe. There is a need for reciprocal healing on multiple scales. Transdisciplinary teams have the potential to address complex socioecological problems, yet they also have inherent challenges. There is a need for new ways of working. This paper details a collaborative

(C) Sara L. Warber et al., 2020; Published by Mary Ann Liebert, Inc. This Open Access article is distributed under the terms of the Creative Commons Attribution Noncommercial License (http://creativecommons.org/licenses/by$\mathrm{nc} / 4.0 /$ ) which permits any noncommercial use, distribution, and reproduction in any medium, provided the original author(s) and the source are cited. and emergent process undertaken to address these challenges. The methods-a combination of established and novel techniques-are important for facilitating transdisciplinary team development and eliciting commitment to shared work. As an example, we share a case study of team building including exploration of literature about environment and health that will inform future work within a multiphase project, Women's Dreams. Grounded in an emergent strategy approach that values addressing complex changes through relatively small interactions, our process incorporated six methods: individual mind mapping, bibliomancy, group processing using sticky notes and paper, group mind mapping, free writing, and synthetic reflection. Emergent themes included healing, story-culture, encountering nature, place, invitation, re-membering, and gathering together. Recurring concepts running through these themes focused on disease, relationship, ways of being, wild wisdom, and reimagining the future. Along with a generative method of team building, we offer invitations to action, both personal and collective, for cultivating reciprocal healing and a future that is more directly sustainable for all, human and more-than-human. Key Words: Environmental change-Environmental psychology-Team development-Naturehealth-Emergent strategy-Mixed methods research.

\section{Introduction}

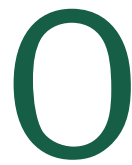

ur time is one of accelerated environmental change and impending environmental catastrophe (Kolbert, 2015). As Debra Roberts of the Intergovernmental Panel on Climate Change (IPCC, 2018) noted, "The decisions we make today are critical in ensuring a safe and sustainable world for everyone... The next few years are probably the most important in our history." Ecosystem health is increasingly linked to human health and well-being (Watts et al., 2018). The United States National Climate Assessment 


\section{TRANSDISCIPLINARY METHODS FOR RECIPROCAL HEALING}

(USGCRP, 2018) now emphasizes health consequences including the lethality and trauma of ecological disasters, heat-induced illness, spread of infectious diseases, increased respiratory disease, food insecurity, and population displacement.

How do we respond to such predictions? We need a recognition of our interdependence with nature and a course charted toward reciprocal healing of humans and sentient nature on multiple scales. Reciprocal healing between humans, such as healers and clients (Rhatz, Bonell, Goldingay, Warber, \& Dieppe, 2017) or physicians and patients (De Conciliis, 2014), may occur when the well-being of both parties is deeply and positively affected during transcendent moments of mutual acknowledgement and intense connection (Dieppe, Goldingay, \& Warber, 2020). Such moments may be possible face-toface with more-than-human nature (Abram, 1996) when sentience is acknowledged and deep interconnection is felt. Collective action can contribute to widening the circle of humans who are sensitized to and prepared to act in light of such experiences. In other words, "As we heal ourselves, we heal the earth-and vice versa" (Fleischner, quoted in Kahn, 2020). In a synthesis of cultural historian and environmental thinker Thomas Berry's work (e.g., Berry, 1999), Schenck (2015, p. 23) argues that to reshape our relationship with nature there is a need for

new means of cultivating ourselves ... to live differently on the earth. Developing and telling the new story is one component ... [This new story is found in] myth, ritual, and dream; in liturgy, poetry, and music; in wisdom literature and renewed philosophies and theologies; in ... painting, sculpture, architecture.

One path toward developing the stories for new ways of living is to bring together people who have different ways of knowing, that is, different epistemological frames. Indeed, given the complexity of the socioecological challenges we face, the need for working across academic disciplines to find solutions is a recurrent theme (e.g., Lubchenco, 1998; van Kerkhoff, 2005). Increasingly, there is recognition for the need to incorporate knowledge not only from within the academy but also from policy and practice (Pohl, 2008). Haraway (2016) also calls for artists to join with scientists/academicians, further expanding possible processes of knowledge generation and effective action. How to bring these differing theoretical frameworks, ways of viewing problems, methods, and time horizons (to name a few) together for synergistic effort is a recognized challenge (Eigenbrode et al., 2007; Tress, Tress, and Fry, 2007). In their reflections on the importance of such transdisciplinary teams, Norris, O'Rourke, Mayer, and Halvorsen (2016) characterize the formation of a transdisciplinary team as a central barrier, framing it as a "wicked" problem (Rittel \& Webber, 1973) in and of itself. Constituting the team and enabling the team to function are key components of team formation. To harvest the benefit of transdisciplinary teams, Norris et al. (2016) stress the need for facilitating processes that equip the collaborators to go beyond established disciplinary and practice ways of doing.

The inherent methodologic tension within transdisciplinary teams is similar to problems in mixed-methods research where quantitative and qualitative data are merged to produce new knowledge. Fetters and Molina-Azorin (2017) identify team integration of multiple content experts as an important dimension of successful mixedmethods research. Curry et al. (2012) suggest that developing a minimum shared commitment to the project, creating a safe space for voicing views, and developing a common language are essential to project group functioning. Still there is little study of procedures such as exploring essential readings and establishing mutual understanding of fundamental concepts that are critical to effective team action (Fetters \& Molina-Azorin, 2017).

This article discusses a transdisciplinary team building approach developed in the context of a mixed-methods research project, Women's Dreams: Nature, Health and a Balanced Life.* The project examines women's visions, stories, and experiences of human and planetary healing with an overall goal of reimagining human ways of living in the context of environmental catastrophe. Products of the project include an interactive website, evaluation of forest therapy for deep relationship and reciprocal healing with nature, and curation/production of a participatory art exhibit that will inspire action toward reciprocal healing.

The project team includes women researchers and practitioners, scientists and artists. Central to moving forward with the multiphase, transdisciplinary project was a need to develop a shared understanding of a body of knowledge drawn from outside and across our respective experiences. Additionally, we needed to effectively and fully engage with the issues identified above as inherently germane to transdisciplinary work. The developed team-building approach is an example of an emergent strategy, an "intentional, adaptive, relational way of being" that seeks to build "complex patterns and systems of change through relatively small interactions" (Brown, 2017, p. 2). Key elements include standing in wonder of life's systems; mindful listening; learning through inspiration, conversation, personal revelations, experience, and reflection; aligning our behavior and our structures with our visions; and embodying dignity, collective power, love, generative conflict, and community.

*For more detail, see https://tiih.org/who/people/scholars-and-fellows/sarawarber 


\section{WARBER ET AL.}

The purpose of this paper, therefore, is to articulate a collaborative and emergent process of transdisciplinary team building which adds to the growing recognition of the advantages and challenges of transdisciplinarity and working across epistemological and methodological differences (Curry et al., 2012; Eigenbrode et al., 2007; Fetters \& Molina-Azorin, 2017; Tress et al., 2007; Norris et al., 2016). As a real-world example of this process, we provide a case study detailing our multimethod approach. We share an exploration of the cross-cutting concepts identified through our process. Additionally, we offer emerging invitations to action that may contribute to reciprocal healing on multiple levels between humans and the morethan-human world.

\section{Case Study}

We participated in a multiday project retreat in a natural setting to solidify our interconnections as a team, to co-develop a shared understanding of existing literature in relation to human-nature healing, to identify central concepts, and to establish a shared vision and language. While we share a Western worldview (United States, United Kingdom), we bring diverse perspectives. These include different ways of knowing-academic research (S.L.W. \& K.N.I.); arts-based practice (A.L.H., C.H., B.F.Q., \& E.S.); disciplinary training in integrative family medicine (S.L.W.), environmental psychology (K.N.I.), arts (A.L.H., B.F.Q., \& E.S.), and education (C.H.); professional experience in accredited land conservation practices (A.L.H.); environmental activism (B.F.Q.)-and diverse life experiences based our spread of ages (35-75). Underlying these surface identities, we found layers of lived experience that instilled a reverence for the earth and linked us to each other with a hope for healing.

\section{Methods}

Our process incorporated six methods: individual mind mapping, bibliomancy, group processing using sticky notes and paper, group mind mapping, free writing, and synthetic reflection. The individual mind mapping occurred before our retreat, while the free writing and synthetic reflection took place after. The other activities were facilitated during the face-to-face retreat. In keeping with the emergent strategy approach, we include not only a description of the methods but also brief reflections on their use and the ways in which the individual methods informed one another and our results.

Step 1. Mind mapping. This offers a quick, intuitive way of assessing a situation or knowledge base (Buzan \& Abbott, 2006). It visually conveys how things are linked or sequenced. While conducting an informal scoping review of literature about climate change and en- vironmental crisis as well as women's writing on nature and health, two authors (S.L.W. \& B.F.Q.) each created individual mind maps. The full team posed the question: Could we make a group mind map? At the retreat, we had available 65 books that were contributed by team members as relevant for considering the intersection of nature, health, and expressive arts. We wondered: How could a group of diversely trained individuals rapidly gain a collective understanding of this body of written material? Such a question lies at the heart of many transdisciplinary projects.

Step 2. Bibliomancy. Divination by the book, dates back to at least the Romans, when the Sibylline books were consulted about anomalous events, like flooding (Moss, 2015). The process involves selecting a book, setting a question, then opening the book at random. With eyes closed, the fingers find the place within the text that conveys the answer or advice. The practice of bibliomancy can be used with spiritual tomes, for example, the Bible or Koran, dependent upon cultural context, or with any other book (e.g., the Iliad). The process may entail prayer or may be secular. Moss (2015, p. 114) asserts, "You'll not only get messages; it's a grand way to become more familiar with a text and to view it from different angles." We used bibliomancy from this secular perspective as a sensitizing exercise. We each thought of a question based on what we wanted to learn related to our project. The technique was rapid and intuitive, molded by the question but with the element of chance inviting synchronicity into the process.

Step 3. Group processing using sticky notes and paper. As each woman spoke her question about the project and related her answer from the bibliomancy practice, the others quickly wrote down resonant words, phrases, or brief reactions on sticky notes. Each individual randomly placed her notes on a table-sized sheet of paper. Following this process, each individual shared what had emerged as meaningful to her about the other's question and answer. We were awed by the synchronicities that emerged and the quality of our sharing. We were ready to take a second dive into the literature.

Step 4. Group mind mapping. Each woman selected one to several books to identify the topics covered and the books' structure (e.g., by author, by topic). Observations were written on sticky notes, which were placed on a second table-sized piece of paper. We collectively grouped words and phrases with similar meanings, labeling each cluster and identifying linkages. The process was a conceptually dynamic exercise in meaning-making as we talked through ideas from selected books. Seven themes were identified: healing, story- 
culture, encountering nature, place, invitation, re-membering, gathering together. One of the facilitators observed that during the development of the group mind map "Everyone who participated was absolutely focused, riffing off of each other's ideas without being hampered by notions of intellectual 'ownership,' or individual 'positioning' in the conversation."

A computer-based version of the collectively developed mind map (Fig. 1) was created using Scapple (version 1.2.3.; Scrivener, 2019). This software was selected because it supports multiple paths for connecting themes rather than being limited to hierarchical relationships.

Step 5. Free writing. This was used to more deeply explore each of the seven themes that emerged from the mind mapping exercise. The technique involves continuously writing whatever comes to mind on a topic or prompt. It is considered a form of prewriting but can also be used to explore feelings, thoughts, imagery, or related content (Elbow, 1973). We each volunteered to write about a theme.

We explored our chosen theme with a meditative, dreamlike mind. We used our "backwoods mind," of the lone person living in the woods. We let the words/phrases associated with each theme sit together and form new meanings, like the transformation of a compost pile. We asked ourselves: What is triggered in me by this theme? We gave ourselves permission to speak, to write poetry, to draw, to find out what would emerge.

Step 6. Synthetic reflection. The individually developed pieces of writing-informed by the co-development of the shared mind mapwere reviewed and summarized using a content analysis qualitative methods perspective (Elo \& Kyngas, 2008; Morgan, 1993). Crosscutting concepts were drawn out and compared back to existing topical literature. Invitations to action were identified and collated.

\section{Cross-cutting concepts}

Dis-ease. This concept weaves together ideas of disease, dissonance, disconnection, and disruption. The dis- prefix alerts us to the dissonant problems around us, stories that alienate us from nature. Disconnection calls out the dis-ease within us that needs healing: disstress, nature-deficit disorder (Louv, 2005). Halifax (1993) described
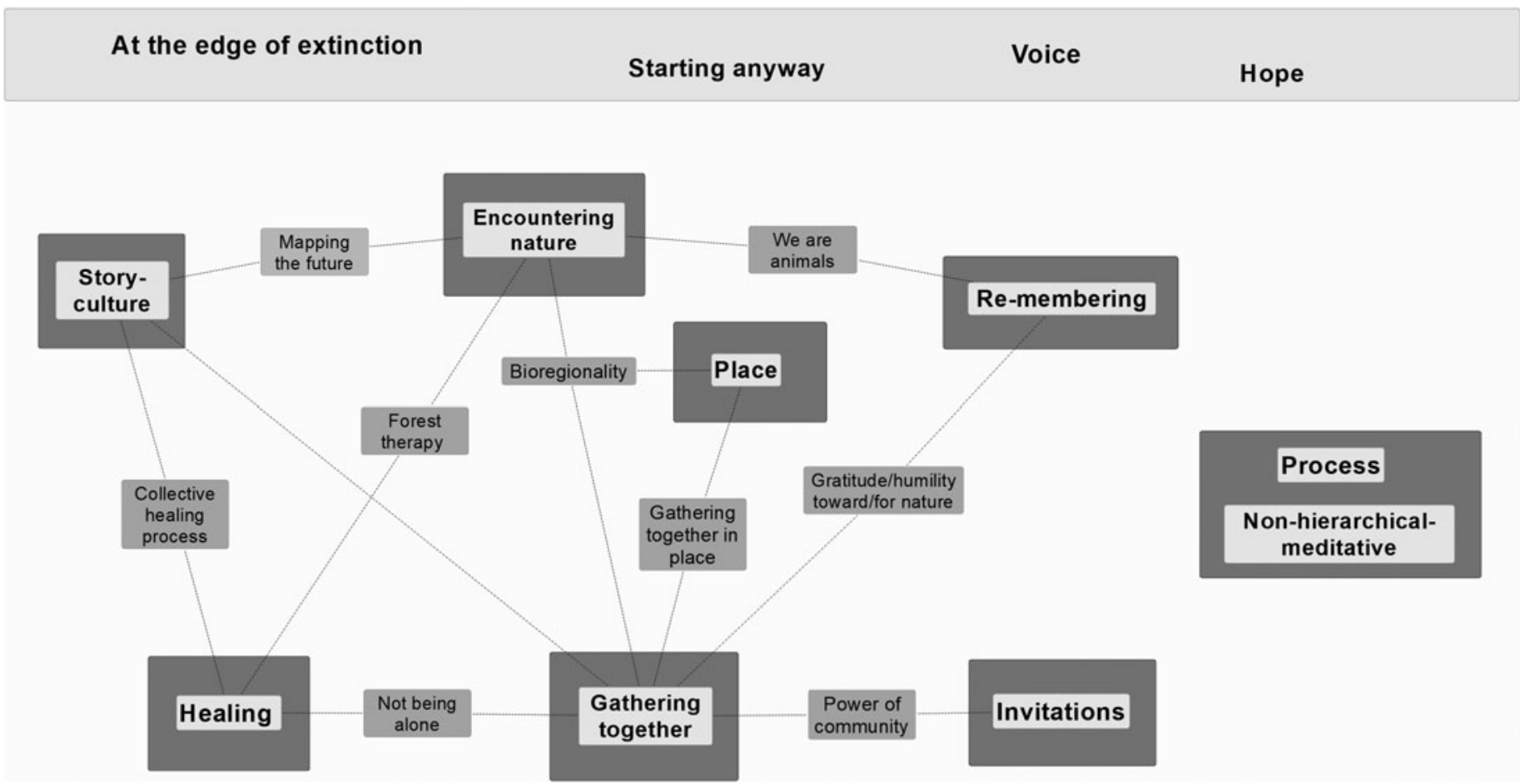

Fig. 1. Collectively developed mind map of selected literature content as presented using Scapple, a mind mapping program. 


\section{WARBER ET AL.}

this parallelism between inner and outer experiences as "the world wound," a complex interrelationship between personal trauma and environmental degradation.

Disruption can provide the turmoil that catapults us into healing, creativity, and action. Bragg (2015) suggests that climate change could be an ally that moves us into the "Great Turning" (Macy \& Chris, 2012) toward a more sustainable and healthful way of life. The earth needs us to face the darkness, feel the dissonance, acknowledge the disconnections, and disrupt our habitual patterns. Nature needs us to become whole. The places we love offer us respite and resilience; in return, we offer our reimagined and renewed action. We step into relationship and reciprocity.

Relationship. Our themes speak of the importance of finding ways to (re)create, tend, and fully engage in healthy relationships between our human and more-than-human world. Gatherings of families, of children, of all peoples; true comings together that reach across differences and generations (ancestral and future). We speak of interconnectedness with Mother Earth. We write of "joining forces with," of "emergent cocreated wisdom" and bringing all of our human-body/mind sensing capacities into collaboration. We imagine natural places as both home and love. This way of relationship can be characterized as friendly or kincentric rather than objectifying and dominant (Haraway, 2016; Kimmerer, 2013; Le Guin, 2017). Litfin (2012) notes that these relationships can contribute to "a deep sense of belonging-to the planet and each other" (p. 131).

Ways of being. We observe a need for cultivating a new way of being in the world that enables wellness, the creation of strong relationships, and reciprocal healing. Our themes draw attention to the relevance of slowness, humility, creativity, embodied and direct engagement, dreaming, dancing, attentiveness, open-heartedness, open-mindedness, gratitude, partnership working, staying flexible, and listening as part of this new way of being. These ways of being echo Brown's (2017) emergent strategy and are naturally suited to developing "the way of nonduality," a perceptual dissolution of the barriers between self and others (Halifax, 1993, p. 137).

Wild wisdom. Where can we seek insight and guidance? Our themes invite us to turn to the more-than-human world. Soil teaches us about ways to steward the land. The varying traits of animals, such as multicolored bird species, and communities of plants remind us of the necessity of diversity for resilience. Natural places allow our inner and outer worlds to (re)connect. The visual and behavioral unity of a flock of birds gives imagery to how we might work together for a different future. There is an acknowledgement of sentience of the more-than-human world, a sense that there is an inherent wisdom. Kimmerer (2013) offers a clear argument for the value of listening to the wisdom of plants. We come into a living relationship; we receive the gift of ancient wisdom.

Reimagining the future. Humans and the sentient life around them need new visions of the future. Old and new stories help us experience new worlds, testing potential outcomes. Our dreams speak messages of possibility. Our bodies and the landscapes we feel connected to help us remember the past, experience the present, and seek the future in relationship. Macy and Chris (2012) call us to cultivate active hope, arguing that "knowing what we hope for and what we'd like or love, to take place" is not enough; "It is what we do with this hope that really makes the difference" (p. 4, emphasis ours). We are called to gather, despite our differences, and to contribute our novel ways of knowing. Those who never lost their connection to the earth emerge as guides toward the new resilient future that embodies health for allthat-is and the possibility of survival, flourishing, and healing.

\section{Invitations to action}

As an example of active hope, we share invitations to action, both personal and collective, that emerged from the original evocative writing generated in the free writing step (Table 1). We invite others to consider these actions that might lead to reciprocal healing and a future that is more directly sustainable for all, human and morethan-human.

\section{Challenges and Opportunities for Transdisciplinary Teamwork}

We need ways to make a difference in the enormously complex, global and political environmental crisis. Despair, anxiety, and helplessness are reasonable reactions as are retreating into knowledge that is known and familiar. It is of utmost urgency, however, to find ways to fruitfully integrate across boundaries (e.g., academic disciplines, policy, practice) to develop insight-and action-toward reciprocal healing of humans and the planet across multiple scales.

To address this challenge, we merged both novel and more commonly used team-building methods with an overall emergent strategy (Brown, 2017). Exploring essential literature is a common yet often unaddressed problem (Fetters \& Molina-Azorin, 2017). We began with individual mind maps but quickly found that these were not satisfactory for transferring understanding to the whole team. Bibliomancy along with group processing and group mind mapping brought the textual material alive and rapidly generated a basic 


\section{Table 1. Invitations to Action Emerging from the Collaborative Mind Map and Free Writing Exercise}

INVITATIONS TO ACTION

\begin{tabular}{|c|c|}
\hline \multirow{5}{*}{$\begin{array}{l}\text { If you want to change } \\
\text { the world, change yourself }\end{array}$} & - Consider your way of life as a creative opportunity \\
\hline & - Do not choose sheer force as the first option \\
\hline & - Make do, even in the face of catastrophes like climate change \\
\hline & - Stretch, reach, grow \\
\hline & - Tend to your own healing, so you can act for nature \\
\hline \multirow[t]{2}{*}{ Go to nature } & - Go to nature to de-stress, find health, heal your separation/isolation, find balance \\
\hline & - Set aside time to intentionally encounter nature face-to-face every day \\
\hline \multirow[t]{6}{*}{ Use your senses } & - Pay attention to your senses. Get to know that which you encounter daily \\
\hline & - Cultivate your ability to observe \\
\hline & - Do small experiments \\
\hline & - Notice nature coming to you \\
\hline & - Notice your connections and relationships with the natural world \\
\hline & $\begin{array}{l}\text { - Use all the sensing capacities of your human body-including intuition, imagination, cognitive capacity, } \\
\text { and heart to collaborate with the more-than-human world }\end{array}$ \\
\hline \multirow{2}{*}{$\begin{array}{l}\text { Change your pace, } \\
\text { tune in to place }\end{array}$} & - Move at the pace of the natural world \\
\hline & - Find places that are holy and private \\
\hline
\end{tabular}




\section{Table 1. (Continued)}

INVITATIONS TO ACTION

Gather together

- Nature is a gathering place

- Come face-to-face with each other and the natural world

Gather together in a million small flocks around the world

Flock together and share stories and your own purpose

Gather with children and listen

Invite a diversity of people to have fun outdoor experiences; nature is for everybody

- Help people feel at home in nature: Make it the place where everyday activities happen

Create comfortable outdoor habitats where people can relax with family and friends

Work together

Build trust

Speak truth and bear witness with an open heart

Join with other humans with an open heart, open mind

Join in dialogue, conversations, actions

Embrace differences, be humble, join hands, dance the circle dance that reawakens the earth

Act for nature

Increase biodiversity in ways that honor the history of a place

Promote forest bathing, creative outdoor endeavors

Encourage gardening and free play

Teach children how to tend to plants and read from nature's book

Tend the children along with trees

Reimagine the way forward

Cherish the earth; do not dominate the earth

Join forces with the more-than-human in true partnership

Work in solidarity with indigenous peoples and those who feel the biophilic pull of connection to community and the natural world

Join those who dream of health, stories, and unifying mysteries

Create a gathering place of local reports from around the world

Find the stories that teach balance

Share old and new stories that reconnect us to the earth, to each other, and to the creative energy around us

- Listen to muted messages that lie deep within ourselves, within our dreams, and within our imaginations

Listen to the quieter capacities of the human mind and body

Give yourself time to imagine and reflect-to dream different ways of being together

Bring your creativity to the problems we face 
TRANSDISCIPLINARY METHODS FOR RECIPROCAL HEALING

Table 1. (Continued)

INVITATIONS TO ACTION

\begin{tabular}{l|l} 
Start now & $\cdot$ Make small incremental changes \\
\cline { 2 - 2 } & - Act as if your actions will change everything \\
\hline · Act again and then again \\
\hline & Despite everything, start anyway \\
\hline
\end{tabular}

common level of knowledge. Establishing mutual understanding of fundamental concepts (Fetters \& Molina-Azorin, 2017) began during group processing and mind mapping but was manifested more fully in the synthetic reflection step. Developing a common language (Curry et al., 2012) was supported by the group processing and mind mapping as well as the free writing and synthetic reflection. Creating a safe space for various views (Curry et al., 2012) was also facilitated by the group processing and mind mapping. The free writing step helped team members trust their own voice and the reception from other team members. The synthetic reflection step helped team members see the inherent value of their ideas.

Our methods reflected the elements of emergent strategies as described by Brown (2017). Group processing and mind mapping require mindful listening. Learning through inspiration can occur with bibliomancy, group processing, and free writing. Conversation drives the bibliomancy and two group processes. Personal revelation happens fluidly during bibliomancy, group processing, and mind mapping and is strongly at work in free writing. Individual experience figures in the group processing as each person identified resonant ideas; personal experience informed each person's free writing. Reflection carried across group processes and free writing and featured prominently in the synthetic reflection tasks. Aligning behavior and structure with vision was active across all the methods and is embodied in the invitations to action.

The approach, in toto, is intentional, relational, and adaptive; it builds the complex through small steps and embodies dignity, collective power, and generative community (Brown, 2017). Bibliomancy, group mind mapping, and free writing served as key disruptors, luring individuals with their lively novelty to go beyond their disciplinary or practice ways of knowing and doing (Curry et al., 2012). In experiencing this approach, utilizing these methods to address major issues of transdisciplinary work, individuals began to embrace an essential shared commitment to the team and to the project vision (Curry et al., 2012).
It is our hope that other transdisciplinary groups attempting to work at the complex intersection of environment and health, nature and healing, will embrace useful elements of a values-based emergent strategy and focus attention on team building to optimize their impact. The novel and established methods described here can be imported as is or modified to suit the situation and stage of team formation. The shared commitment, language, concepts, understanding, and vision garnered will more than make up for the time expended and may chart the way toward a future that is more directly healing for all-individuals, communities, and the more-than-human world.

\section{Acknowledgments}

All authors contributed free writing, reviewed, and edited the final manuscript. Conceptualization was undertaken by S.L.W. and K.N.I.; S.L.W., K.N.I., and B.F.Q. prepared the initial full draft of the manuscript. We thank two anonymous reviewers and the guest editors for their critique. We thank Emmylou Rahtz, Exeter Medical School, Truro, UK, for reviewing an earlier draft.

\section{Author Disclosure Statement}

No competing financial interests exist.

\section{Funding Information}

The project was supported by an award from the Institute for Integrative Health, (S.L.W., K.N.I., B.F.Q., A.L.H., \& C.H.), with additional support from the Scottish Government's Rural and Environment Sciences and Analytical Services Division (K.N.I.) and Michigan Medicine Gifts of Art (E.S.).

\section{REFERENCES}

Abram, D. (1996). The spell of the sensuous: Perception and language in a morethan-human world. New York, NY: Pantheon.

Berry, T. (1999). The great work: Our way into the future. New York, NY: Harmonyl Bell Tower. 


\section{WARBER ET AL.}

Bragg, E.E. (2015). What if...? Climate change as ally. Ecopsychology 7, 231-237. Brown, A. M. (2017). Emergent strategy: Shaping change, changing worlds. Chico, CA: AK Press.

Buzan, T., \& Abbott, S. (2006). The ultimate book of mind maps: Unlock your creativity, boost your memory, change your life. London, UK: Thorsons.

Curry, L. A., O'Cathain, A., Clark, V. L. P., Aroni, R., Fetters, M., \&t Berg, D. (2012). The role of group dynamics in mixed methods health sciences research teams. Journal of Mixed Methods Research, 6, 5-20.

De Conciliis, A. J. (2014). Reciprocal healing in healthcare. Ochner Journal, 14, $310-$ 311.

Dieppe, P., Goldingay, S., \& Warber, S. L. (2020). Healing and wellness. In W. W. IsHak (Ed.), The Handbook of wellness medicine. Cambridge, UK: Cambridge University Press. Book in press.

Eigenbrode, S., O'Rourke, M., Wulfhorst, J. D., Althoff, D. M., Goldberg, C. S., Merrill, K., Morse, W., Nielsen-Pincus, M., Stephens, J., Winowiecki, L., \& Bosque-Pérez, N. A. (2007). Employing philosophical dialogue in collaborative science. BioScience, 57, 55-64.

Elbow, P. (1973). Freewriting exercises. In: Writing without Teachers. New York, NY: Oxford University, pp. 3-11.

Elo, S., \& Kyngas, H. (2008). The qualitative content analysis process. Journal of Advanced Nursing, 62, 107-115.

Fetters, M. D., \& Molina-Azorin, J. F. (2017). The Journal of Mixed Methods Research starts a new decade: The Mixed Methods Research Integration Trilogy and its dimensions. Journal of Mixed Methods Research, 11, 291-307.

Halifax, J. (1993). The fruitful darkness: Reconnecting with the body of the earth. San Francisco, CA: Harper.

Haraway, D. J. (2016). Staying with the trouble: Making kin in the Chthulucene. Durham, NC: Duke University Press.

IPCC. (2018, October 8). Summary for policymakers of IPCC Special Report on global warming of $1.5^{\circ} \mathrm{C}$ approved by governments (Press release). Retrieved from https://www.ipcc.ch/site/assets/uploads/2018/11/pr_181008_P48_spm_en.pdf

Kahn, P. (2020, March 28) Reciprocal healing: Nature, health, and wild vitality. University of Washington Nature and Health. Retrieved from https://natureandhealth.uw.edu/ 2020/03/reciprocal-healing-nature-health-and-wild-vitality

Kimmerer, R. W. (2013). Braiding sweetgrass: Indigenous wisdom, scientific knowledge and the teachings of plants. London, UK: Penguin Books.

Kolbert, E. (2015). Field notes from a catastrophe: Man, nature, and climate change. New York, NY: Bloomsbury.

Le Guin, U. K. (2017). Deep in admiration. In A. L. Tsing, N. Bubandt, E. Gan, \& H. A. Swanson (Eds.), Arts of living on a damaged planet: Ghosts and monsters of the Anthropocene (pp. 15-21). Minneapolis, MN: University of Minnesota.

Litfin, K. (2012). A whole new way of life: Ecovillages and the revitalizing of deep community. In R. De Young \& T. Princen (Eds.), The localization reader: Adapting to the coming downshift. Cambridge, MA: MIT Press.

Louv, R. (2005) Last child in the woods: Saving our children from nature-deficit disorder. Chapel Hill, NC: Algonquin Books of Chapel Hill.
Lubchenco, J. (1998). Entering the century of the environment: A new social contract for science. Science, 279, 491-497.

Macy, J., \& Chris, J. (Eds.). (2012). Active hope: How to face the mess we're in without going crazy. Novato, CA: New World Library.

Morgan, D. L. (1993). Qualitative content analysis: A guide to paths not taken. Qualitative Health Research, 3, 112-121.

Moss, R. (2015). Sidewalk oracles: Playing with signs, symbols, and synchronicity in everyday life. Novato, CA: New World Library.

Norris, P. E., O'Rourke, M., Mayer, A. S., \& Halvorsen, K. E. (2016). Managing the wicked problem of transdisciplinary team formation in socio-ecological systems. Landscape and Urban Planning, 154, 115-122.

Pohl, C. (2008). From science to policy through transdisciplinary research. Environmental Science and Policy, 11, 46-53.

Rhatz, E., Bonell, S., Goldingay, S., Warber, S., \& Dieppe, P. (2017). Transformational changes in health status: A qualitative exploration of healing moments. Explore, 13, 298-305

Rittel, H. W., \& Webber, M. M. (1973). Dilemmas in a general theory of planning. Policy Sciences, 4, 155-169.

Schenck, D. (2015). The great teaching work of Thomas Berry. Minding Nature Journal, 8, 23-26.

Scrivener. (2019) Scapple [Computer software]. Cornwall, UK: Literature \& Latte.

Tress, G., Tress, B., \& Fry, G. (2007). Analysis of the barriers to integration in landscape research projects. Land Use Policy, 24, 374-385.

USGCRP. (2018). Fourth national climate assessment, Volume II: Impacts, risks, and adaptation in the United States. Washington, DC: U.S. Global Change Research Program. Retrieved from https://nca2018.globalchange.gov

van Kerkhoff, L. (2005). Integrated research: Concepts of connection in environmental science and policy. Environmental Science and Policy, 8, 452-463.

Watts, N., Amann, M., Arnell, N., Ayeb-Karlsson, S., Belesova, K., Berry, H., ... Costello, A. (2018). The 2018 report of the Lancet Countdown on health and climate change: Shaping the health of nations for centuries to come. The Lancet, 392, 2479-2514.

Address correspondence to:

Sara L. Warber

Department of Family Medicine

The University of Michigan

1018 Fuller Street

Ann Arbor, MI 48104

USA

E-mail: swarber@umich.edu

Received: January 6, 2020

Accepted: May 31, 2020 